\title{
Appraisal of resistant genotypes against brinjal shoot and fruit borer (BSFB), Leucinodes orbonalis, Guenee
}

\author{
Hafija Sultana ${ }^{1}$, Md. Aabdul Mannan², Md. Mostofa Kamal'², Khan Golam Quddus² and Shimul Das ${ }^{2}$ \\ ${ }^{1}$ Soil Resource Development Institute, Dhaka, Bangladesh \\ ${ }^{2}$ Agrotechnology Discipline, Khulna University, Khulna-9208, Bangladesh
}

\begin{tabular}{|c|c|}
\hline ARTICLE INFO & \\
\hline & \multirow{3}{*}{$\begin{array}{l}\text { The main purpose of this study was to find out the best variety of brinjal having resistance to BSFB. A pot } \\
\text { experiment was carried out at the germplasm centre, Agrotechnology Discipline, Khulna University, } \\
\text { Khulna during February } 2014 \text { to August } 2014 \text {. The experiment was laid out in CRD using thirteen } \\
\text { varieties with five replications. The varieties were } \mathrm{V}_{1}=\mathrm{BARI} \text { begun-1, } \mathrm{V}_{2}=\mathrm{BARI} \text { begun- } 4, \mathrm{~V}_{3}=\mathrm{BARI} \\
\text { begun-5, } \mathrm{V}_{4}=\mathrm{BARI} \text { begun- } 6, \mathrm{~V}_{5}=\mathrm{BARI} \text { begun-7, } \mathrm{V}_{6}=\mathrm{BARI} \text { begun- } 8, \mathrm{~V}_{7}=\mathrm{BARI} \text { begun- } 9, \mathrm{~V}_{8}=\mathrm{BARI} \text { I } \\
\text { begun-10, } \mathrm{V}_{9}=\text { Makra, } \mathrm{V}_{10}=\text { Muktokashi, } \mathrm{V}_{11}=\text { Lalita, } \mathrm{V}_{12}=\text { Hazra, } \mathrm{V}_{13}=\text { Chaga. Data were collected on total } \\
\text { number of shoot, total number of infested shoot, percentage of shoot damage, percentage of shoot } \\
\text { infestation reduction, numbers of larvae per infested shoot, total number of fruit, percentage of fruit } \\
\text { damage, percentage of fruit infestation reduction, numbers of larvae per infested fruit. Results have shown } \\
\text { that the minimum shoot infestation was found in BARI begun- } 6(29.60 \%, 32.40 \% \text {, } 29.86 \% \text { and } 29.38 \% \text {, } \\
\text { respectively at four different stages of eggplant). Percent of fruit infestation was minimum in } \mathrm{V}_{4} \text { (BARI } \\
\text { begun-6) }(25.16 \%, 27.42 \% \text { and } 25.40 \% \text { at three stages respectively). }\end{array}$} \\
\hline ladesn & \\
\hline & \\
\hline
\end{tabular}

\section{Introduction}

Brinjal (Solanum melongena L.) is one of the important vegetables in South and South-East Asia (Thapa, 2010) cultivation of which helps to improve human nutrition and generate income. It is cultivated more than 1.6 million ha of land producing about 50 million MT throughout the globe (FAO, 2012). The higher yield and harvesting period lure the farmer on eggplant production (Ghimire et al., 2007). But in Bangladesh it covers about $15 \%$ of the total vegetable area of the country producing 1.6 million MT annually. The production of brinjal is severely affected by the incidence of different insect pests from seedling to fruiting stage (Latif et al., 2009) and eight insect species are considered as major pests causing damage to this crop in Bangladesh (Biswas et al., 1992). Among them the brinjal shoot and fruit borer, BSFB (Leucinodes orbonalis, Guenee) is the most destructive insect pests (Alam, 1969) which caused 31$86 \%$ fruit damage in Bangladesh (Alam et al., 2003) reaching up to $90 \%$ (Rahman, 1997). The situation of brinjal production is in threat in the recent years due to increased cost of production for the management of insect pest. Farmers of Bangladesh in most cases solely depend on insecticides for the management of this pest. Such dependence on insecticides has created many problems such as excessive residues on marketed vegetables that concerns general consumer's health and the environment, pesticide resistance, trade implications, poisoning, hazards to non-target organisms, increased production costs etc. (Alam et al., 2003; Pedigo, 2002).
Now-a-days, importance is given on the use of resistant genotype against BSFB. Because the use of resistant variety is non-toxic and safe alternatives to the conventional chemical control (Anil and Pandey, 2001; Dolui and Debnath, 2010). There was no naturally selected brinjal varieties available having resistance to BSFB except transgenic Bt brinjal varieties. So, for the production of brinjal fruit with minimum environmental hazards, the present study was undertaken to evaluate some genotype from Bangladesh for their resistance properties against BSFB.

\section{Materials and Methods}

\section{Experimental site}

The experiment was conducted at the germplasm centre, Agrotechnology Discipline, Khulna University, Khulna during February 2014 to August 2014. The soil used in bags was collected from the garden of germplasm centre of Agrotechnology Discipline, Khulna University, Khulna. The average character of the soil was clay loam to clay. After collecting the soil it was sun dried and ground well. Then the soil debris was removed by sieving and the soil was put into bags after mixing with manure and fertilizer.

\section{Plant material used and raising of seedlings}

Seeds were collected from local market of Khulna and Bangladesh Agricultural Research Institute (BARI) and raised as seedling in germplasm centre of Khulna University, used in the experiment. Brinjal seedling was 
raised in seedbed of $3 \mathrm{~m} \times 1 \mathrm{~m}$ size. The soil was well prepared and converted into loose friable and dried mass by spading. All weeds and stubbles were removed. Weeding, mulching and irrigation were done when required.

Design and layout of the experiment, Preparation of bags and Transplanting of brinjal seedlings

The experiment was laid out in CRD using thirteen varieties with five replications. In this experiment medium size bazaar bags were selected as growing container. Each bag was filled-up with sun dried soil and kept under natural light. Cowdung was uniformly incorporated to the soil before filling bags. The rest half dose of cowdung, full TSP, one-third Urea and one-third MoP were mixed during pit preparation in the bag. Rest of the Urea and MoP were applied 21 DAT, 35 DAT and 50 DAT. The bags were pre-labeled for each variety. Healthy seedlings were uprooted from the seedbed and were transplanted in the experimental bags during late afternoon on February, 2014.

\section{Treatments of the experiment}

Eight improved varieties released by BARI and 5 local cultivar were used as treatment. The brinjal varieties were

$\mathrm{V}_{1}=$ BARI begun -1

$\mathrm{V}_{2}=$ BARI begun -4

$\mathrm{V}_{3}=$ BARI begun -5

$\mathrm{V}_{4}=$ BARI begun- 6

$\mathrm{V}_{5}=$ BARI begun- 7

$\mathrm{V}_{6}=$ BARI begun -8

$\mathrm{V}_{7}=$ BARI begun -9

$\mathrm{V}_{8}=$ BARI begun -10

$\mathrm{V}_{9}=$ Makra

$\mathrm{V}_{10}=$ Muktokashi

$\mathrm{V}_{11}=$ Lalita

$\mathrm{V}_{12}=$ Hazra

$\mathrm{V}_{13}=$ Chaga.

\section{Intercultural operations}

After transplanting of seedlings, various intercultural operations were accomplished for better growth and development of the plants. When the brinjal seedlings were well established, the soil around the base of each seedling was pulverized. A few gaps filling was done by healthy seedlings of the same stock where initially planted seedlings failed to survive. Weeding and mulching were accomplished as and whenever necessary to keep the crop free from weeds, for better soil aeration and to break the crust. It also helped in soil moisture conservation. Irrigations were given throughout the growing period at 10-15 days interval. The irrigations were given to increase the yield.

\section{Harvesting and Data collection}

Harvesting of fruits was started at 60 days after transplanting and continued up to 150 days after transplanting with an interval of 7 days. Harvesting was usually done manually. In order to know the effects of the treatments of controlling BSFB, data in respect of the following parameters were collected from vegetative to late fruiting stage. Data were collected on total number of shoot, total number of infested shoot, percentage of shoot damage, percentage of shoot infestation reduction, numbers of larvae per infested shoot, total number of fruit, percentage of fruit damage, percentage of fruit infestation reduction, numbers of larvae per infested fruit.

\section{Percentage of infested shoots was calculated using the following formula:}

Percentage of shoots damage $=$

$\frac{\text { Numbers of infested shoot/plant }}{\text { Total number of shoot/plant }} \times 100$

Percentage of fruits damage was calculated using the following formula:

Percentage of fruits damage $=$

$\underline{\text { Numbers of infested fruit/plant }} \times 100$

Total number of fruit/plant

\section{Data analysis}

Data were analyzed by using MSTAT-C software for analysis of variance after square root transformation for per stage data. ANOVA was made by $\mathrm{F}$ variance test and the pair comparisons were performed by Duncan's Multiple Range Test (DMRT) (Gomez \& Gomez, 1984).

\section{Results and Discussion}

Shoot infestation at different stages of brinjal

The percent shoot infestation by brinjal shoot and fruit borer (BSFB) at different varieties of eggplant at different stages was statistically significant (Table 1). Among thirteen varieties the highest percent shoot infestation was recorded in chaga at Vegetative stage and Late fruiting stage and at Early fruiting stage and Mid fruiting stage, the highest percent shoot infestation by brinjal shoot and fruit borer (BSFB) was observed in Makra varieties and the minimum shoot infestation was found in BARI Begun- 6 at all stages among the varieties $(29.60 \%, 32.40 \%, 29.86 \%$ and $29.38 \%$ respectively at all four stages).

\section{Fruit infestation in different stages of brinjal}

The percent fruit infestation by brinjal shoot and fruit borer (BSFB) in different varieties of eggplant at different stages was statistically significant (Table 2). Among thirteen varieties the highest percent fruit infestation by brinjal shoot and fruit borer (BSFB) at three different stages was recorded in chaga $(75.28 \%$, $74.40 \%$ and $73.90 \%$ ) at early, mid and late fruiting stage respectively and the minimum in BARI Begun-6 $(25.16 \%, 27.42 \%$ and $25.40 \%)$ at early, mid and late fruiting stage respectively. 
Table 1. Shoot infestation (in percentage) by brinjal shoot and fruit borer (BSFB) at different stages

\begin{tabular}{|c|c|c|c|c|}
\hline Varieties & $\begin{array}{c}\text { Vegetative stage (30-60 } \\
\text { DAT) }(\%) \\
\end{array}$ & $\begin{array}{l}\text { Early fruiting stage } \\
(60-90 \text { DAT })(\%)\end{array}$ & $\begin{array}{l}\text { Mid fruiting stage } \\
(90-120 \text { DAT) }(\%) \\
\end{array}$ & $\begin{array}{l}\text { Late fruiting stage } \\
(120-150 \text { DAT })(\%) \\
\end{array}$ \\
\hline BARI begun-1 & 43.47abcde & $50.19 b c$ & $51.06 \mathrm{~cd}$ & $48.70 \mathrm{de}$ \\
\hline BARI begun-4 & $41.79 \mathrm{bcde}$ & $43.83 \mathrm{~d}$ & $35.87 \mathrm{f}$ & $41.99 \mathrm{f}$ \\
\hline BARI begun-5 & $34.17 \mathrm{def}$ & $35.54 \mathrm{e}$ & $34.56 \mathrm{f}$ & $34.06 \mathrm{~g}$ \\
\hline BARI begun-6 & $29.60 \mathrm{f}$ & $32.40 \mathrm{e}$ & $29.86 f$ & $29.38 \mathrm{~g}$ \\
\hline BARI begun-7 & $41.90 \mathrm{bcde}$ & $43.75 d$ & $44.20 \mathrm{e}$ & $43.07 f$ \\
\hline BARI begun- 8 & $33.33 \mathrm{ef}$ & $32.82 \mathrm{e}$ & $32.92 \mathrm{f}$ & $31.47 \mathrm{~g}$ \\
\hline BARI begun- 9 & $52.14 \mathrm{ab}$ & $52.58 \mathrm{bc}$ & $54.44 \mathrm{bc}$ & $50.56 \mathrm{~cd}$ \\
\hline BARI begun-10 & 43.33abcde & $42.82 \mathrm{~d}$ & $44.90 \mathrm{de}$ & $44.05 \mathrm{ef}$ \\
\hline Makra & $40.00 \mathrm{cdef}$ & $60.36 \mathrm{a}$ & $62.03 \mathrm{a}$ & $60.02 \mathrm{a}$ \\
\hline Muktokashi & 46.00abcd & $47.46 \mathrm{~cd}$ & $51.43 \mathrm{~cd}$ & 48.16de \\
\hline Lalita & $51.43 \mathrm{abc}$ & $54.25 \mathrm{ab}$ & $56.36 \mathrm{abc}$ & $55.07 \mathrm{bc}$ \\
\hline Hazra & $50.00 \mathrm{abc}$ & $55.40 \mathrm{ab}$ & $56.75 \mathrm{abc}$ & $56.07 \mathrm{ab}$ \\
\hline Chaga & $54.00 \mathrm{a}$ & $59.210 \mathrm{a}$ & $59.62 \mathrm{ab}$ & $60.94 a$ \\
\hline LS & $* *$ & $* *$ & $* *$ & $* *$ \\
\hline CV (\%) & 14.60 & 7.42 & 7.95 & 6.00 \\
\hline
\end{tabular}

LS $=$ Level of Significance, $* *=$ Significant at $1 \%$ level

Means followed by common letter(s) in a column do not differ significantly by DMRT

$\mathrm{CV}=$ Coefficient of Variation

Table 2. Fruit infestation (in percentage) by brinjal shoot and fruit borer (BSFB) at different stages

\begin{tabular}{cccc}
\hline Varieties & $\begin{array}{c}\text { Early fruiting stage }(60-90 \\
\text { DAT) }(\%)\end{array}$ & $\begin{array}{c}\text { Mid fruiting stage }(90- \\
120 \mathrm{DAT})(\%)\end{array}$ & $\begin{array}{c}\text { Late fruiting stage (120- } \\
150 \mathrm{DAT})(\%)\end{array}$ \\
\hline BARI begun-1 & $37.68 \mathrm{fg}$ & $37.04 \mathrm{hi}$ & $38.60 \mathrm{~g}$ \\
BARI begun-4 & $40.18 \mathrm{f}$ & $40.24 \mathrm{gh}$ & $40.14 \mathrm{fg}$ \\
BARI begun-5 & $44.24 \mathrm{f}$ & $44.88 \mathrm{fg}$ & $44.88 \mathrm{f}$ \\
BARI begun-6 & $25.16 \mathrm{~h}$ & $27.42 \mathrm{j}$ & $25.40 \mathrm{~h}$ \\
BARI begun-7 & $29.22 \mathrm{~h}$ & $30.38 \mathrm{j}$ & $30.38 \mathrm{~h}$ \\
BARI begun-8 & $51.86 \mathrm{e}$ & $50.14 \mathrm{ef}$ & $50.88 \mathrm{e}$ \\
BARI begun-9 & $31.82 \mathrm{gh}$ & $32.40 \mathrm{ij}$ & $31.06 \mathrm{~h}$ \\
BARI begun-10 & $55.44 \mathrm{de}$ & $55.48 \mathrm{de}$ & $54.82 \mathrm{de}$ \\
Makra & $69.98 \mathrm{ab}$ & $69.28 \mathrm{ab}$ & $68.76 \mathrm{ab}$ \\
Muktokashi & $72.82 \mathrm{a}$ & $72.08 \mathrm{ab}$ & $70.76 \mathrm{a}$ \\
Lalita & $59.52 \mathrm{~cd}$ & $60.06 \mathrm{~cd}$ & $59.30 \mathrm{~cd}$ \\
Hazra & $64.90 \mathrm{bc}$ & $65.96 \mathrm{bc}$ & $64.30 \mathrm{bc}$ \\
Chaga & $75.28 \mathrm{a}$ & $74.40 \mathrm{a}$ & $73.90 \mathrm{a}$ \\
LS & $* *$ & $* *$ & $* *$ \\
CV $(\%)$ & 8.55 & 7.05 & 7.01 \\
\hline
\end{tabular}

$\mathrm{LS}=$ Level of Significance, $* *=$ Significant at $1 \%$ level

Means followed by common letter(s) in a column do not differ significantly by DMRT

$\mathrm{CV}=$ Coefficient of Variation

Larvae in infested shoot and fruit at different stages Number of Larvae in infested shoot and fruit in different varieties was statistically significant (Table 3 ). The maximum mean number of larvae per infested shoot was recorded in chaga at vegetative, early, mid and late fruiting stage respectively and the minimum in BARI Begun- 8 at vegetative stage early, mid and late fruiting stage respectively. The maximum mean number of larvae per infested fruits was recorded in chaga at early, mid and late fruiting stage respectively and the minimum larvae per infested fruits was recorded in BARI Begun- 8 at early, mid and late fruiting stage respectively. 
Table 3. Mean number of larvae per infested shoot and per infested fruit at different stages

\begin{tabular}{|c|c|c|c|c|c|c|c|}
\hline \multirow[b]{2}{*}{ Varieties } & \multicolumn{4}{|c|}{ Mean number of larvae per infested shoot } & \multicolumn{3}{|c|}{ Mean number of larvae per infested fruit } \\
\hline & $\begin{array}{c}\text { Vegetative } \\
\text { stage (30- } \\
\text { 60DAT) }\end{array}$ & $\begin{array}{c}\text { Early } \\
\text { fruiting stage } \\
(60-90 \\
\text { DAT })\end{array}$ & $\begin{array}{l}\text { Mid fruiting } \\
\text { stage }(90- \\
120 \text { DAT) }\end{array}$ & $\begin{array}{l}\text { Late fruiting } \\
\text { stage }(120- \\
150 \text { DAT })\end{array}$ & $\begin{array}{c}\text { Early fruiting } \\
\text { stage }(60-90 \\
\text { DAT) }\end{array}$ & $\begin{array}{c}\text { Mid fruiting } \\
\text { stage }(90-120 \\
\text { DAT) }\end{array}$ & $\begin{array}{c}\text { Late fruiting } \\
\text { stage }(120- \\
150 \text { DAT) }\end{array}$ \\
\hline BARI begun-1 & $2.00 \mathrm{e}$ & $2.15 \mathrm{f}$ & $1.73 \mathrm{e}$ & $1.64 f g$ & $2.03 \mathrm{gh}$ & $1.93 \mathrm{fg}$ & $1.84 \mathrm{fg}$ \\
\hline BARI begun-4 & $2.15 \mathrm{de}$ & $2.22 \mathrm{f}$ & $1.96 \mathrm{de}$ & $1.86 \mathrm{ef}$ & $2.47 \mathrm{fg}$ & $2.36 \mathrm{ef}$ & $2.25 \mathrm{ef}$ \\
\hline BARI begun-5 & $2.40 \mathrm{~d}$ & $2.38 f$ & 2.04de & $1.91 \mathrm{ef}$ & $2.56 \mathrm{f}$ & $2.42 \mathrm{e}$ & $2.32 \mathrm{e}$ \\
\hline BARI begun-6 & $1.70 \mathrm{f}$ & $1.40 \mathrm{~g}$ & $1.71 \mathrm{e}$ & $1.34 \mathrm{gh}$ & 1.89hi & $1.76 \mathrm{gh}$ & $1.66 \mathrm{gh}$ \\
\hline BARI begun-7 & $2.75 \mathrm{c}$ & $2.74 \mathrm{ef}$ & $2.23 \mathrm{~d}$ & $2.15 \mathrm{de}$ & $2.70 \mathrm{ef}$ & $2.58 \mathrm{de}$ & $2.44 \mathrm{de}$ \\
\hline BARI begun- 8 & $1.16 \mathrm{~g}$ & $1.25 \mathrm{~g}$ & $1.19 \mathrm{f}$ & $1.07 \mathrm{~h}$ & $1.52 \mathrm{i}$ & $1.44 \mathrm{~h}$ & $1.32 \mathrm{~h}$ \\
\hline BARI begun-9 & $2.89 \mathrm{c}$ & $2.74 \mathrm{ef}$ & $2.68 \mathrm{c}$ & $2.50 \mathrm{~cd}$ & $3.10 \mathrm{e}$ & $2.96 \mathrm{~d}$ & $2.84 \mathrm{~d}$ \\
\hline BARI begun-10 & $3.20 \mathrm{~b}$ & $3.40 \mathrm{~cd}$ & $2.92 b c$ & $2.79 b c$ & $4.25 b c$ & $4.06 \mathrm{~b}$ & $3.94 b$ \\
\hline Makra & $4.47 \mathrm{a}$ & $4.12 \mathrm{ab}$ & $4.34 \mathrm{a}$ & $4.11 \mathrm{a}$ & $4.37 b$ & $4.17 b$ & $4.04 \mathrm{~b}$ \\
\hline Muktokashi & $4.39 \mathrm{a}$ & $4.22 \mathrm{ab}$ & $4.26 \mathrm{a}$ & $4.06 \mathrm{a}$ & $3.70 \mathrm{~d}$ & $3.54 \mathrm{c}$ & $3.36 \mathrm{c}$ \\
\hline Lalita & $3.26 \mathrm{~b}$ & $3.02 \mathrm{de}$ & $3.26 \mathrm{~b}$ & $2.88 \mathrm{bc}$ & $3.87 \mathrm{~cd}$ & $3.72 b c$ & $3.60 \mathrm{bc}$ \\
\hline Hazra & $3.24 b$ & $3.72 b c$ & $3.30 \mathrm{~b}$ & $3.06 \mathrm{~b}$ & $3.88 \mathrm{~cd}$ & $3.74 b c$ & $3.62 b c$ \\
\hline Chaga & $4.53 \mathrm{a}$ & $4.48 \mathrm{a}$ & $4.30 \mathrm{a}$ & $4.08 \mathrm{a}$ & $4.96 \mathrm{a}$ & $4.76 \mathrm{a}$ & $4.56 \mathrm{a}$ \\
\hline $\mathrm{LS}$ & $* *$ & $* *$ & $* *$ & $* *$ & $* *$ & $* *$ & $* *$ \\
\hline $\mathrm{CV}(\%)$ & 5.04 & 11.58 & 9.04 & 9.60 & 8.49 & 8.53 & 9.16 \\
\hline
\end{tabular}

$\mathrm{LS}=$ Level of Significance, $* *=$ Significant at $1 \%$ level

Means followed by common letter(s) in a column do not differ significantly by DMRT

$\mathrm{CV}=$ Coefficient of Variation

Yield performance of different brinjal varieties Significant difference $(\mathrm{p} \leq 0.01)$ was found in different varieties in terms of yield performance (Table 4). The highest Number of fruits per plant was found in BARI begun-1 (60.00) and in BARI begun-4 (60.00) and the lowest in muktokashi (14.04). The maximum Weight of fruits per plant was recorded in BARI begun-10 (4.70) and the minimum in lalita (2.13). The BARI begun-6 showed moderate yield.

Table 4. Yield Performance of different varieties

\begin{tabular}{ccc}
\hline Varieties & $\begin{array}{c}\text { Number of fruits } \\
\text { per plant }\end{array}$ & $\begin{array}{c}\text { Weight of fruits } \\
\text { per plant }(\mathrm{Kg})\end{array}$ \\
\hline BARI begun-1 & $60.00 \mathrm{a}$ & $3.77 \mathrm{bc}$ \\
BARI begun-4 & $60.00 \mathrm{a}$ & $3.35 \mathrm{~cd}$ \\
BARI begun-5 & $42.00 \mathrm{~b}$ & $4.20 \mathrm{ab}$ \\
BARI begun-6 & $30.00 \mathrm{~cd}$ & $3.15 \mathrm{cde}$ \\
BARI begun-7 & $26.00 \mathrm{de}$ & $2.85 \mathrm{def}$ \\
BARI begun-8 & $33.60 \mathrm{c}$ & $3.23 \mathrm{bcd}$ \\
BARI begun-9 & $27.20 \mathrm{de}$ & $2.99 \mathrm{cde}$ \\
BARI begun-10 & $44.80 \mathrm{~b}$ & $4.704 \mathrm{a}$ \\
Makra & $15.60 \mathrm{gh}$ & $3.12 \mathrm{cde}$ \\
Muktokashi & $14.40 \mathrm{~h}$ & $2.45 \mathrm{ef}$ \\
Lalita & $16.40 \mathrm{fgh}$ & $2.13 \mathrm{f}$ \\
Hazra & $22.40 \mathrm{ef}$ & $3.14 \mathrm{cde}$ \\
Chaga. & $21.60 \mathrm{efg}$ & $3.20 \mathrm{cde}$ \\
Level of & $* *$ & $* *$ \\
significance & & \\
CV $(\%)$ & 11.26 & 13.23 \\
\hline
\end{tabular}

$* *=$ Significant at $1 \%$ level

Means followed by common letter(s) in a column do not differ significantly by DMRT

$\mathrm{CV}=$ Coefficient of Variation

Resistance of different brinjal varieties against brinjal shoot and fruit borer (BSFB) infestation

Resistance of different brinjal varieties against brinjal shoot and fruit borer (BSFB) infestation was varied significantly at $1 \%$ level. The maximum Number of fruits per plant was found in BARI begun-1 (60.00) and in BARI begun-4 (60.00) respectively and the minimum was recorded in muktokashi (14.40). The highest Number of infested fruits per plant was found in BARI begun-1 (17.40) and the lowest in BARI begun-6 (5.80). The maximum Percent of fruit infestation was observed in muktokashi (59.05) and the minimum in BARI begun6 (19.28) (Table 5). Yadav and Sharma (2005) was conducted a field experiment to observe the infestation by shoot and fruit borer in aubergine cultivars. Three out of twelve cultivars of aubergine were found to be less susceptible to $L$. orbonalis with infestation less than $25 \%$.

Table 5. Resistance of different brinjal varieties against brinjal shoot and fruit borer (BSFB) infestation

\begin{tabular}{cccc}
\hline Varieties & $\begin{array}{c}\text { Number of } \\
\text { fruits per plant }\end{array}$ & $\begin{array}{c}\text { Number of } \\
\text { infested fruits } \\
\text { per plant }\end{array}$ & $\begin{array}{c}\text { Percent of fruit } \\
\text { infestation }\end{array}$ \\
\hline BARI begun-1 & $60.00 \mathrm{a}$ & $17.40 \mathrm{a}$ & $29.09 \mathrm{cdef}$ \\
BARI begun-4 & $60.00 \mathrm{a}$ & $16.60 \mathrm{ab}$ & $27.52 \mathrm{def}$ \\
BARI begun-5 & $42.00 \mathrm{~b}$ & $14.40 \mathrm{~b}$ & $34.30 \mathrm{~cd}$ \\
BARI begun-6 & $30.00 \mathrm{~cd}$ & $5.80 \mathrm{e}$ & $19.28 \mathrm{~g}$ \\
BARI begun-7 & $26.00 \mathrm{de}$ & $6.00 \mathrm{e}$ & $23.09 \mathrm{fg}$ \\
BARI begun-8 & $33.60 \mathrm{c}$ & $10.00 \mathrm{c}$ & $30.00 \mathrm{cde}$ \\
BARI begun-9 & $27.20 \mathrm{de}$ & $7.20 \mathrm{de}$ & $26.60 \mathrm{ef}$ \\
BARI begun-10 & $44.80 \mathrm{~b}$ & $15.60 \mathrm{ab}$ & $34.86 \mathrm{c}$ \\
Makra & $15.60 \mathrm{gh}$ & $8.40 \mathrm{cde}$ & $53.93 \mathrm{a}$ \\
Muktokashi & $14.40 \mathrm{~h}$ & $8.40 \mathrm{cde}$ & $59.05 \mathrm{a}$ \\
Lalita & $16.40 \mathrm{fgh}$ & $8.80 \mathrm{~cd}$ & $57.33 \mathrm{a}$ \\
Hazra & $22.40 \mathrm{ef}$ & $9.80 \mathrm{~cd}$ & $43.67 \mathrm{~b}$ \\
Chaga. & $21.60 \mathrm{efg}$ & $9.40 \mathrm{~cd}$ & $43.42 \mathrm{~b}$ \\
Level of & $* *$ & $* *$ & $* *$ \\
significance & & 13.70 & 10.16 \\
CV (\%) & 11.26 & & \\
\hline
\end{tabular}

$* *=$ Significant at $1 \%$ level

Means followed by common letter(s) in a column do not differ significantly by DMRT

$\mathrm{CV}=$ Coefficient of Variation 


\section{Conclusion}

Our results have showed that BARI begun- 6 have minimum shoot and fruit infestation percentage caused by brinjal shoot and fruit borer (BSFB). Although, it has medium yield performance. The growers could be motivated to cultivate BARI begun- 6 for efficient management of brinjal shoot and fruit borer (BSFB).

\section{References}

Alam, M. Z. 1969. Insect pest of vegetables and their control in East Pakistan. The Agriculture Information service, Dept. Agric.; East Pakistan, p. 146.

Alam, S. N., Rashid, M. A., Rouf, F. M. A., Jhala, R. C., Patel, J. R., Satpathy, S., Shivalingaswamy, T.M., Wahundeniya, S.Rai, I., Ammaranan, A., Cork, C. and Talekar, N. S. 2003. Development of an integrated pest management strategy for eggplant fruit and shoot borer in South Asia. Shanhua, Taiwan: AVRDC - the World Vegetable Center. Technical Bulletin No. 28. AVRDC Publication No. 03-548. p. 56.

Anil, K. and Pandey, M. C. 2001. Role of Biopesticides in plant protection system. Biopest Conf. BET., Chandigarh, India. p.113.

Biswas, G. C., Sattar, M. A. and Saba, M. C. 1992. Survey and monitoring of insect pests of brinjal at Khagrachari Hilly Region. Annual Report, 1991-92, Entom. Div., BARI, Joydebpur, Gazipur. pp. 44-42.

Dolui, A. K. and Debnath, M. 2010. Antifeedant activity of plant extracts to an insect Helopeltis theivora. J. Environ. Biology. 31(5): 557-559.
Food and Agricultural Organization (FAO) 2012. FAOSTAT data 2012 (Avalilable at: http://www.fao.org Retrived on 25 February, 2014).

Ghimire, S. N., Upreti, G., Thapa, R. B. and Manandhar, D. N. 2007. Ecofriendly management of brinjal fruit and shoot borer, Leucinodes orbonalis Guenee (Lepidoptera: Pyralidae). IAAS Res. Advances. 2: 127-131.

Gomez, K. A. and Gomez, A. A. 1984. Statistical procedures for agricultural research. $2^{\text {nd }}$ edition. International Rice Research Institute, John Willey and Sons, Singapore. p. 490

Latif, M. A., Rahman, M. M., Alam, M. Z. and Hossain, M. M. 2009. Evaluation of Flubendiamide as an IPM Component for the Management of brinjal shoot and fruit borer, Leucinodes Orbonalis Guenee. Mun. Entom. Zool. 4 (1): 257-267.

Pedigo, L. P. 2002. Entomology and Pest Management. 4th Edition. Prentice Hall, Upper Saddle River, New Jersey, USA. p. 633.

Rahman, A. K. M. Z. 1997. Screening of 28 brinjal line for resistance/tolerance against the brinjal shoot and fruit borer. Annual Report. Entom. Div., Bangladesh Agricultural Research Institute, Joydebpur, Gazipur, Bangladesh. pp. 32-35.

Thapa, R. B. 2010. Integrated management of brinjal fruit and shoot borer, Leucinodes orbonalis Guenee: An overview. J. Inst. Agric. Anim. Sci. 30 \& 32: 1-16.

Yadav, D. S. and Sharma, M. M. 2005. Evaluation of brinjal varieties for their resistance against fruit and shoot borer, Leucinodes orbonalis Guenee. Indian J. Entom. 67(2): 129-132. 